\title{
Most colitis associated carcinomas lack expression of LGR5: a preliminary study with implications for unique pathways of carcinogenesis compared to sporadic colorectal carcinoma
}

Mai Iwaya ${ }^{1,2,3^{*}}$ (D) Hiroyoshi Ota ${ }^{4}$, Tomoyuki Nakajima ${ }^{3}$, Takeshi Uehara ${ }^{3}$, Robert Riddell ${ }^{1,2}$ and James Conner ${ }^{1,2}$

\begin{abstract}
Background: Leucine-rich repeat-containing G-protein-coupled receptor 5 (LGR5), a component of the Wnt receptor complex, is thought to lineage label gastric and intestinal stem cells. LGR5 expression is increased in colorectal carcinoma (CRC) compared to normal tissue. Colitis associated colorectal adenocarcinoma (CAC) often shows distinct morphologic and molecular phenotypes compared to sporadic cases. However, the expression profile of LGR5, and by extension the potential role of an intestinal stem cell phenotype, has not been well described in a series of human CAC.
\end{abstract}

Method: RNA in situ hybridization (ISH) for LGR5 expression on 30 CACs (12 cases with conventional morphology and 18 cases with non-conventional type morphology) from 29 inflammatory bowel disease (IBD) patients was performed and compared the expression profile to a control group of 10 sporadic CRCs. Immunohistochemistry for beta-catenin and SATB2 was performed on the 30 CACs.

Result: LGR5 was positive in 30\% (9/30) of CAC cases and 90\% (9/10) of sporadic CRCs ( $p=0.002)$. A large majority (89\%) of LGR5 positive CACs were of the conventional histologic type, and conventional type CAC showed a significantly higher $L G R 5$ score (median 3.0; interquartile range 1.75-3.25) than non-conventional type CAC (median 1.5; interquartile range 1.00-2.00) $(p=0.034)$. CAC with conventional morphology did have a lower level of LGR5 expression than sporadic CRC. Sporadic CRCs showed a significantly higher LGR5 level score than non-conventional type CACs $(p<0.001)$. Nuclear translocation of beta-catenin was strongly associated with $L G R 5$ expression $(p=0.003)$, however no significant association was identified between SATB2 expression and LGR5 expression status in CACs.

Conclusion: These findings suggest that the wider spectrum of tumor morphology in CAC may be associated with absence of a LGR5-expressing intestinal stem cell phenotype.

Keywords: Inflammatory bowel disease, Ulcerative colitis, Crohn's disease, Colitis associated colorectal carcinoma, LGR5

\footnotetext{
* Correspondence: mkatou@shinshu-u.ac.jp

'Department of Pathology and Laboratory Medicine, Mount Sinai Hospital, Toronto, Canada

${ }^{2}$ Department of Laboratory Medicine and Pathobiology, University of Toronto, Toronto, Canada

Full list of author information is available at the end of the article
}

C C The Author(s). 2021 Open Access This article is licensed under a Creative Commons Attribution 4.0 International License, which permits use, sharing, adaptation, distribution and reproduction in any medium or format, as long as you give appropriate credit to the original author(s) and the source, provide a link to the Creative Commons licence, and indicate if changes were made. The images or other third party material in this article are included in the article's Creative Commons licence, unless indicated otherwise in a credit line to the material. If material is not included in the article's Creative Commons licence and your intended use is not permitted by statutory regulation or exceeds the permitted use, you will need to obtain permission directly from the copyright holder. To view a copy of this licence, visit http://creativecommons.org/licenses/by/4.0/. The Creative Commons Public Domain Dedication waiver (http://creativecommons.org/publicdomain/zero/1.0/) applies to the data made available in this article, unless otherwise stated in a credit line to the data. 


\section{Background}

Inflammatory bowel disease (IBD) is a chronic relapsingremitting disorder of the gastrointestinal tract, and for patients with long-standing colonic inflammation, colorectal adenocarcinoma (CRC) is a recognized complication, leading to routine periodic surveillance of patients with colitis for dysplasia and carcinoma. One meta-analysis estimated that the risk of colitis associated carcinoma (CAC) in patients with IBD is $2 \%$ by 10 years after initial diagnosis, and increases to $8 \%$ at 20 years and $18 \%$ at 30 years after colitis onset [1]. However more recent figures are lower than this, likely the results of better treatment reducing the risk $[2,3]$.

Leucine-rich repeat-containing G-protein-coupled receptor 5 (LGR5), a wingless-type mouse mammary tumor virus integration site family (Wnt) target gene that functions as a receptor for Wnt agonist R-spondins (RSPOs). It was identified as a selective marker of crypt base columnar cells, and these LGR5-positive crypt base columnar cells were demonstrated to be self-renewing, multipotent adult intestinal stem cells [4]. Increased LGR5 expression in human sporadic colorectal adenomas and cancers [5-8] and in murine models $[9,10]$ have been well described, however, the LGR5 expression profile has not been described in a series of CAC in human.

Recent studies have highlighted genetic, morphologic, and immunohistochemical differences between CAC and sporadic CRC, and suggested that chronic inflammation may lead to unique genomic changes that increase the risk for CAC $[11,12]$. Carcinogenic mutations probably first start accumulating in the long-lived stem cell lineages of the crypt, as the lifespan of non-stem cells is too short for them to acquire the necessary mutations before being shed.

To our knowledge, a comparison of LGR5 expression in CAC and sporadic CRC has not been performed. Here, a series of CAC cases was compared with sporadic CRC for morphologic features and the expression of LGR5.

\section{Methods}

Study approval was obtained from the Research Ethics Board at Mount Sinai Hospital.

Thirty cases of surgically resected colitis associated primary colorectal adenocarcinoma from 29 patients between 2011 and 2016 were retrieved from the surgical pathology archives at Sinai Health System. Patients who underwent neoadjuvant therapy were excluded. 10 cases of surgically resected primary CRC from patients without inflammatory bowel disease or any known hereditary cancer syndrome, hence forth termed sporadic CRC were identified as a control group. All H\&E sections were reviewed at a multiheaded microscope by four gastrointestinal pathologists ( $\mathrm{MI}, \mathrm{HO}, \mathrm{RR}$, and $\mathrm{JC})$ and each invasive carcinoma was subclassified by consensus into one of five morphologic subtypes: conventional, mucinous, serrated, low grade tubuloglandular (LGTG) and others [13].

One representative paraffin block of tumor was selected in each case for RNA in situ hybridization (ISH). Detection of LGR5 mRNA was performed using the RNAscope ${ }^{\bullet}$ kit (Advanced Cell Diagnostics, Hayward, CA, USA) according to the manufacturer's instructions using unstained sample tissue slides. Briefly, tissue sections were pretreated by heating and protease application prior to hybridization with an LGR5-specific probe. A detailed procedure has been described in an earlier publication [14].

Formalin fixation -paraffin embedding and preservation of formalin-fixed paraffin-embedded (FFPE) tissues were performed according to College of American pathologists protocol (https://documents.cap.org/documents/practicalguide-specimen-handling.pdf). RNA-ISH was performed immediately after cutting sections from FFPE blocks. Positive staining was indicated by brown punctate dots in the nucleus and/or cytoplasm. The expression level of LGR5 was quantified according to the five-grade scoring system previously described [8]: $0=$ no staining or less than one dot per cell; $1=1$ to 3 dots per cell; $2=4$ to 10 dots per cell and no or very few dot clusters; $3=>10$ dots per cell and $<10 \%$ positive cells overall; and $4=>10$ dots per cell and $>10 \%$ positive cells with dot clusters. For a binary analysis, $L G R 5$ status was considered positive if the ISH score was $>2$. (Fig. 1) [15] Immunohistochemical staining was performed using commercially available antibodies with the immuno-enzyme polymer method (Novolink Polymer Detection Systems for beta-catenin, Leica, Germany or Histofine Simple Stain MAX PO Multi for SATB2, Nichirei Biosciences, Tokyo, Japan) with 3, 3'-diaminobenzidone as the chromogen. The primary antibodies were used in accordance with the manufacturers' instructions: beta-catenin (clone: EP35, EPITOMICS, Burlingame, California USA) and SATB2 (clone: EPNCIR130A, abcam, Cambridge, UK). Beta-catenin nuclear staining was classified as negative or scattered; no or very few scattered positive cells without any clusters, focal; positive cells clustered in focal areas, diffuse; positive cells distributed diffusely, homogeneously or heterogeneously in accordance with the previous study [16]. The extent of staining for SATB2 was scored semiquantitatively (no staining; < 5\%; 5-25\%; 26-50\%; 51-75\%; and $76-100 \%$ ), and the maximum intensity was graded as negative, weak, moderate, or strong. For binary analyses, cases with $5 \%$ or more tumor cells showing moderate or strong intensity were considered positive [13].

Two of the authors (MI and JC) reviewed the RNA-ISH stains, and two of the authors (MI and $\mathrm{HO}$ ) reviewed the immunohistochemical stains at a multiheaded microscope and reached a consensus score for each case. 


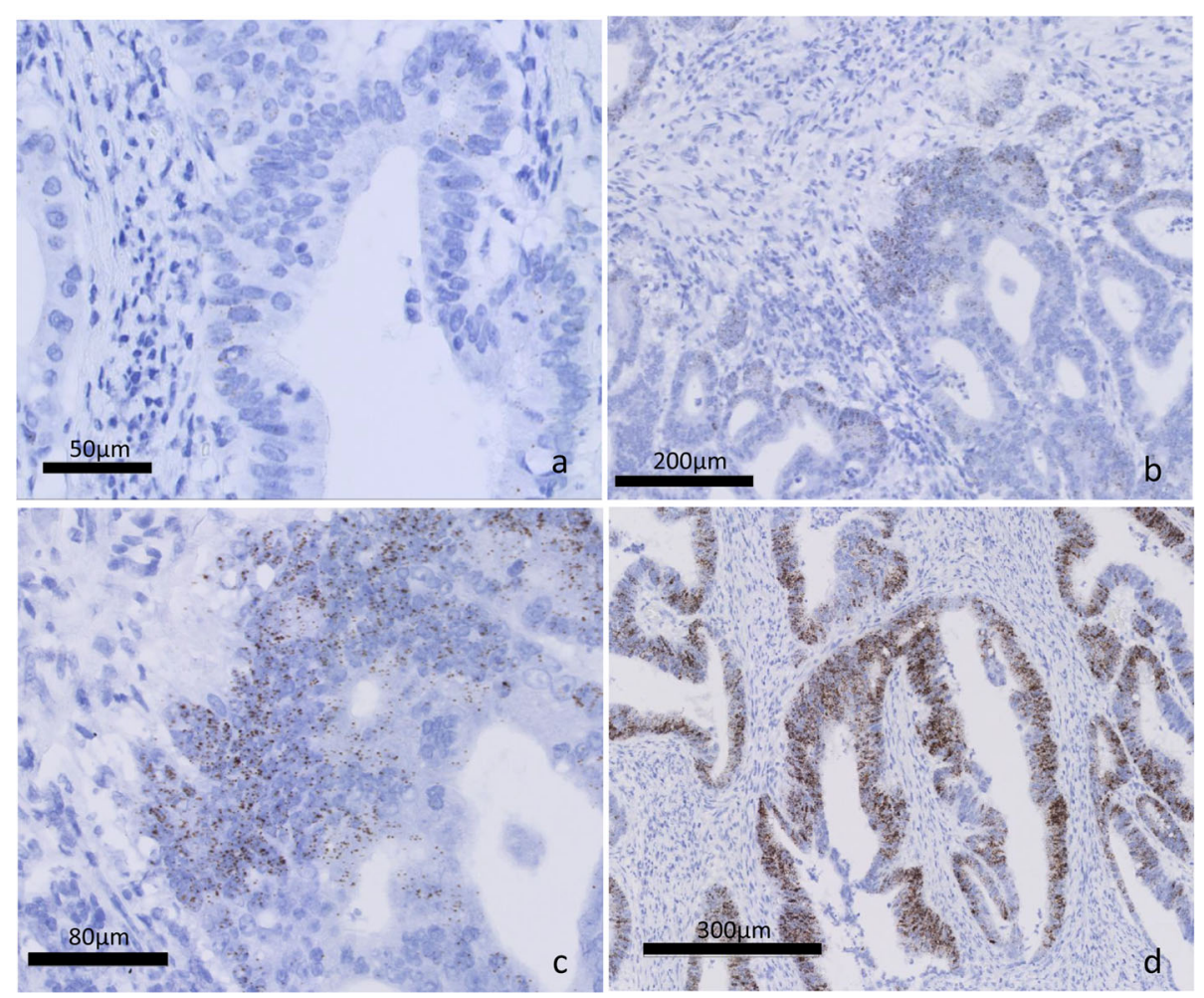

Fig. 1 LGR5 expression level was quantified according to the five-grade scoring system: score 2; a few dots per cell and no or very few dot; LGR5 negative $(\mathbf{a})$, score $3 ;>10$ dots per cell and $<10 \%$ positive cells overall; LGR5 positive, $(\mathbf{b}, \mathbf{c})$, and score $4 ;>10$ dots per cell and $>10 \%$ positive cells; LGR5 positive (d)

\section{Statistics}

Chi-square test or Fisher exact tests were used to characterize the relationship between categorical variables. Kruskal-Wallis chi-squared test and Mann-Whitney Utest were used for comparisons between LGR5 expression level scores. Staining scores are non-parametric and are thus expressed as a median score with the interquartile range. Differences were considered to be significant at $p<$ 0.05. All statistical analyses were performed with EZR (Saitama Medical Center, Jichi Medical University, Saitama, Japan), which is a graphical user interface for $\mathrm{R}$ (The R Foundation for Statistical Computing, Vienna, Austria).

\section{Results}

The 29 patients with CAC included 18 with ulcerative colitis and 11 with Crohn's disease. One patient with ulcerative colitis had synchronous carcinomas for a total of 30 tumors evaluated. A summary of the clinicopathologic features of the CAC cohort and sporadic controls is presented in Table 1 . The median age at time of resection for patients with CAC was 54 years (range 26-76), significantly younger than sporadic cases (median age 67 years; range $40-95)(p=0.017)$. CACs had a wider spectrum of tumor morphologies compared to sporadic CRCs. Only twelve of 30 (40\%) CACs had conventional morphology compared to $80 \%$ of sporadic cases. None of sporadic cases were classified as LGTG. The one CAC case subclassified as "other" showed fetal enteric and hepatoid differentiation.

Adjacent non-neoplastic colonic mucosa was examined as an internal control for LGR5 expression. In all cases, there were measurable brown dots in the base of crypts in control areas. LGR5 was positive in 30\% (9/30) of CAC cases (median 2.0, interquartile range 1.00-3.00) and $90 \%(9 / 10)$ of sporadic CRCs (median 4.0, interquartile range 3.00-4.00) $(p=0.002)$. In CACs, the distribution of LGR5 expression was heterogenous in the overlying mucosa and in some cases, overlying or adjacent dysplasia showed higher expression than the invasive component. An abrupt transition to LGR5 expression was identified in the CAC or dysplasia component in some cases. (Fig. 2) A large majority (89\%) of LGR5 positive CAC cases were of the conventional histologic type, while morphologies were much more variable in the LGR5 negative CAC cases. (Fig. 2) In conventional type CACs, eight of 12 cases (67\%) were LGR5 positive (median 3.0; interquartile range $1.75-3.25)$ and in contrast, only one of 18 (6\%) non- 
Table 1 Clinicopathologic features of study group patients

\begin{tabular}{|c|c|c|c|}
\hline Clinical and pathologic features & $\begin{array}{l}\text { CAC } \\
\text { (N [\%]) }\end{array}$ & $\begin{array}{l}\text { Sporadic CRCs } \\
\text { (N [\%]) }\end{array}$ & $p$ \\
\hline No. of Cases & 30 & 10 & \\
\hline Sex, male/female & $19 / 11$ & $5 / 5$ & 0.482 \\
\hline Median age (range) (y) & $54(26-76)$ & $67(40-95)$ & 0.017 \\
\hline \multicolumn{4}{|l|}{ Location } \\
\hline colon & $22(73)$ & $8(80)$ & \multirow[t]{2}{*}{1} \\
\hline rectum & $8(27)$ & $2(20)$ & \\
\hline \multicolumn{4}{|l|}{ pT stage } \\
\hline 1 & $8(27)$ & $1(10)$ & \multirow[t]{4}{*}{0.144} \\
\hline 2 & $4(13)$ & $2(20)$ & \\
\hline 3 & $15(50)$ & $3(30)$ & \\
\hline 4 & $3(10)$ & $4(40)$ & \\
\hline \multicolumn{4}{|l|}{ pN stage } \\
\hline 0 & $16(53)$ & $5(50)$ & \multirow[t]{2}{*}{1} \\
\hline 1 or 2 & $14(47)$ & $5(50)$ & \\
\hline \multicolumn{4}{|l|}{ Cancer subtypes } \\
\hline Conventional & $12(40)$ & $8(80)$ & \multirow[t]{5}{*}{0.243} \\
\hline Mucinous & $9(30)$ & $1(10)$ & \\
\hline Serrated & $3(10)$ & $1(10)$ & \\
\hline LGTG & $5(17)$ & $0(0)$ & \\
\hline Other & $1(3)$ & $0(0)$ & \\
\hline \multicolumn{4}{|l|}{ LGR5 } \\
\hline Positive & $9(30)$ & $9(90)$ & \multirow[t]{7}{*}{0.002} \\
\hline (Score 3) & $6(20)$ & $3(30)$ & \\
\hline (Score 4) & $3(10)$ & $6(60)$ & \\
\hline Negative & $21(70)$ & $1(10)$ & \\
\hline (Score 0) & $2(7)$ & $0(0)$ & \\
\hline (Score 1) & $9(30)$ & $0(0)$ & \\
\hline (Score 2) & $10(33)$ & $1(10)$ & \\
\hline
\end{tabular}

CAC indicates colitis associated colorectal adenocarcinoma

conventional type CACs (one with serrated morphology) was LGR5 positive (median 1.5; interquartile range 1.00-2.00) $(p<0.001)$. Conventional type CAC showed a significantly higher level of LGR5 expression than non-conventional type CAC $(p=0.034)$. Conventional type CACs showed a lower level of LGR5 expression than sporadic CRCs, but this did not reach statistical significance $(p=0.221)$, whereas, expression level of LGR5 in non-conventional type CACs was significantly lower compared to sporadic CRCs $(p<0.001)$. (Fig. 3).

In CACs, LGR5 expression was associated with nuclear beta catenin expression, but not with SATB2 expression; only two of 21 (10\%) LGR5 negative CACs showed diffuse nuclear beta-catenin expression, while 6 of 9 (67\%)
LGR5 positive CACs showed diffuse nuclear-beta catenin expression $(p=0.003)$. Eleven of 30 CACs $(37 \%)$ retained SATB2 expression and the expression rate was 33 and $44 \%$ in $L G R 5$ positive CACs and LGR5 negative CACs, respectively ( $p=0.687)$.

LGR5 positive CACs were more likely to be located in the rectum $(p=0.032)$. There was no significant difference in $\mathrm{pT}$ stage, $\mathrm{pN}$ stage, IBD phenotype, age, or sex between LGR5 positive CACs and negative CACs. (Table 2).

\section{Discussion}

Here, we evaluated the LGR5 expression profile of 30 CAC cases and 10 sporadic CRC cases and identified that LGR5 was less frequently expressed in CACs than 

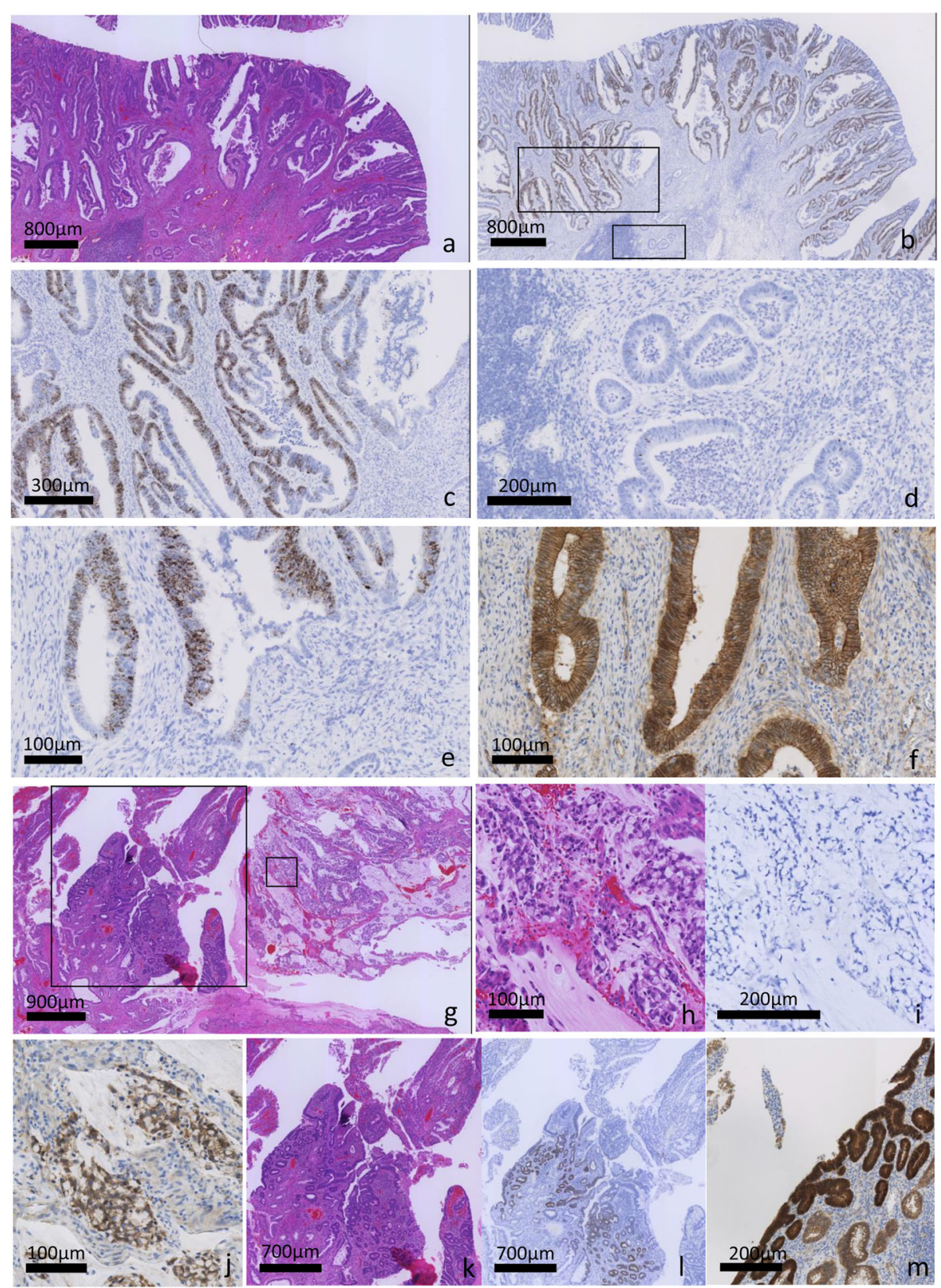

Fig. 2 LGR5 expression in colitis associated adenocarcinoma (CAC). CAC with conventional morphology (a) often showed diffuse and strong LGR5 expression (b and c: high power view; score 4), however a few invasive glands adjacent to the LGR5 positive area were LGR5 negative. No morphological differences between these areas was apparent (d). An LGR5 positive invasive component (e) showed nuclear translocation of betacatenin (f). A high grade mucinous CAC had adjacent dysplasia with focal adenomatous morphology (g). The mucinous component was negative for LGR5 (h); however, nuclear translocation of beta catenin was identified (i). Adjacent dysplasia with adenomatous morphology showed strong LGR5 expression (I) and nuclear expression of beta catenin ( $\mathbf{m})$

in sporadic CRCs. Further, we found CAC with nonconventional morphology showed significantly lower LGR5 expression levels and nuclear translocation of beta-catenin than the conventional subtype of CAC.

LGR5 has been considered one of the most reliable crypt stem cell markers of CRCs, particularly those that arise through the $A P C$-mutant pathway of tumorigenesis [9]. LGR5 is reportedly overexpressed in human colorectal adenomas and cancers by immunohistochemistry $[6,17$, 18] and ISH [15], and Martin et al. showed that the mRNA levels of LGR5 expressed in human CRCs is 10-fold expanded than normal intestinal crypt [19]. Jang et al. recently 


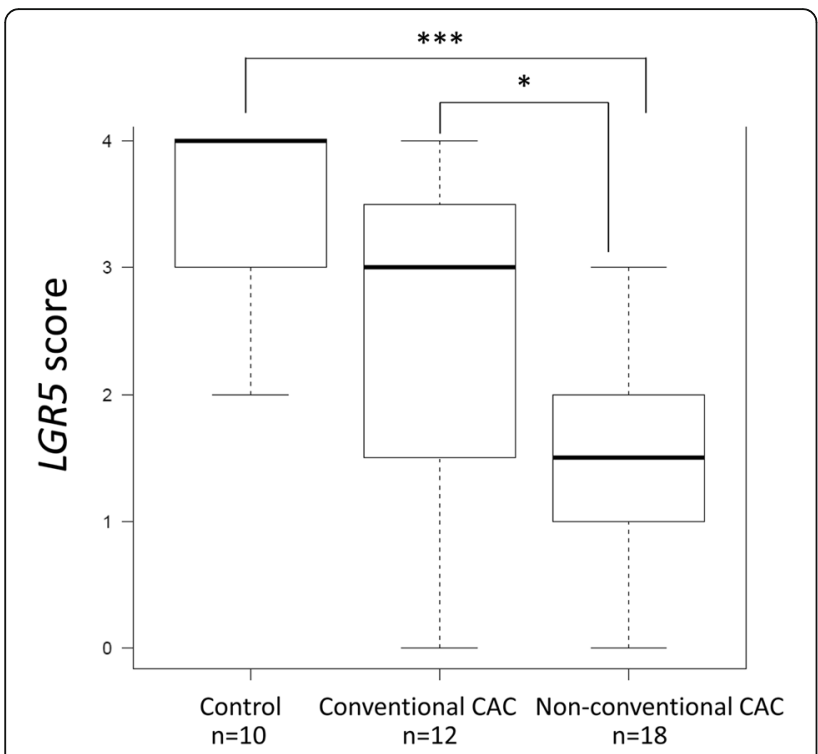

Fig. 3 Expression level of LGR5 in control sporadic colorectal adenocarcinoma, conventional type colitis associated adenocarcinoma and non-conventional type colitis associated adenocarcinoma. ${ }^{*} P=0.034,{ }^{* * *} P<0.001$

showed that LGR5 mRNA positivity is observed in $68 \%$ of 788 human CRCs and suggested positive correlation with the chromosomal-instability pathway (characterized by leftsided location and nuclear $\beta$-catenin expression; representing an abnormal Wht signal activation) and negative correlation with MSI, CIMP-high, and BRAF mutations [15]. In accordance with these findings, we found positive LGR5 expression in $90 \%$ of our sporadic CRC control group. However, only $30 \%$ of CAC were LGR5 positive. The latter finding is in agreement with the previous study by Yasuda et al. reporting significantly less expression of reliable intestinal stem cell markers such as CD133 [20], OCT4 [21] and NANOG [22] in CAC than sporadic CRC [23]. The molecular pathogenesis of CAC is different than that of sporadic CRCs with genomic changes that appear directly linked to the effects of ongoing inflammation and repeated mucosal injury in the IBD $[11,12]$. In keeping with this, we recently reported CAC tends to show nonconventional tumor morphology and loose intestinal markers such as SATB2 and CDX2, and show aberrant gastric mucin expression [13], Ishibashi et al. described the expression profile of Atonal homolog-1 (ATOH1), a master transcription factor of the secretory lineage of intestinal epithelial cells, which retain their potential to revert to intestinal stem cells [24-26] in colitic mucosa. They identified both ATOH1 and LGR5 double positive tumor cells as well as LGR5 single positive tumor cells, suggesting that colitic tumors are mosaic and consisted of a heterogenous population of tumor stem cell [27].
Our data also support this interpretation given the heterogeneous distribution of LGR5 expression in the dysplastic and invasive components of some cases. While the exact mechanism of decreased LGR5 expression in CAC is uncertain, these data demonstrate that CACs have a unique expression profile of intestinal stem cell markers.

We found that despite only $40 \%$ of CACs in our cohort showing a conventional morphology, 89\% of LGR5 positive CAC were conventional in appearance. These also tended to be located in the rectum and associated with nuclear beta-catenin staining. This raises the possibility that the minority of CACs in our cohort that showed conventional morphology might have arisen through the conventional APC pathway. However, as the majority of tumors had non-conventional morphology and were also $L G R 5$ negative, our data provide support to other recent studies demonstrating that most CAC cases do not arise through the conventional $A P C$ pathway $[12,28]$. Although it did not reach statistical significance, conventional type CACs trended toward a lower level of $L G R 5$ expression compared to the control group of sporadic CRCs. Thus, even in tumors arising through more conventional molecular pathways in the setting of colitis, LGR5 expression might be affected by ongoing inflammation and repeated mucosal injury. This hypothesis is supported by other studies showing that Lgr5+ stem cells are highly sensitive to epithelial injury induced by radiation or colitis [27, 29, 30].

Our results in human cancers do not entirely align with previous data from animal models of colitis. Kim et al. reported increased Lgr5 expression in an AOM / DSS - colitis mouse model. They showed that Lgr5 expression is gradually increased as tumors developed with repeated colitis and reported all dysplastic lesions and cancers showed high Lgr5 expression [10]. This discrepancy could be due to differences between human $\mathrm{CAC}$ and the murine model. Interestingly, the figure showing tumor morphology in their report shows a more conventional morphology, implying that the murine model may simulate the carcinogenesis pathway in the conventional type of human CAC.

Data regarding any potential prognostic significance of LGR5 expression in sporadic CRC are mixed. Recent studies using RNA-ISH for LGR5 evaluation reported that LGR5 expression is an independent predictor of favorable outcome in CRCs [15, 31]. On the contrary, a previous meta-analyses of immunohistochemical studies of LGR5 expression showed that high LGR5 expression is associated with shorter overall survival and disease free survival [32, 33].

Kazama et al. described the immunohistochemical expression profile of LGR5 in ulcerative colitis cases and showed increased LGR5 expression in dysplasia and CAC 
Table 2 Clinicopathologic Features of LGR5 positive CACs and LGR5 negative CACs

\begin{tabular}{|c|c|c|c|}
\hline & $\begin{array}{l}\text { LGR5 positive CACs } \\
\text { (N [\%]) }\end{array}$ & $\begin{array}{l}\text { LGR5 negative CACs } \\
\text { (N [\%]) }\end{array}$ & $\mathbf{p}$ \\
\hline No. of Cases & 9 & 21 & \\
\hline Sex, male/female & $5 / 4$ & $14 / 7$ & 0.687 \\
\hline Median age (range) (y) & $53(24-76)$ & $54(31-65)$ & 0.557 \\
\hline \multicolumn{4}{|l|}{ Location } \\
\hline colon & $4(44)$ & $18(86)$ & \multirow[t]{2}{*}{0.032} \\
\hline rectum & $5(56)$ & $3(14)$ & \\
\hline \multicolumn{4}{|l|}{ pT stage } \\
\hline 1 & $4(44)$ & $4(19)$ & \multirow[t]{4}{*}{0.471} \\
\hline 2 & $1(11)$ & $3(14)$ & \\
\hline 3 & $4(44)$ & $11(52)$ & \\
\hline 4 & $0(0)$ & $3(14)$ & \\
\hline \multicolumn{4}{|l|}{ pN stage } \\
\hline 0 & $6(67)$ & $10(47)$ & \multirow[t]{2}{*}{0.440} \\
\hline 1 or 2 & $3(33)$ & $11(52)$ & \\
\hline \multicolumn{4}{|l|}{ Cancer subtypes } \\
\hline Conventional & $8(89)$ & $4(19)$ & $<0.001$ \\
\hline Mucinous & $0(0)$ & $9(42)$ & 0.029 \\
\hline Serrated & $1(11)$ & $2(10)$ & 1 \\
\hline LGTG & $0(0)$ & $5(24)$ & 0.286 \\
\hline Other & $0(0)$ & $1(5)$ & 1 \\
\hline \multicolumn{4}{|l|}{ Immunohistochemistry } \\
\hline \multicolumn{4}{|l|}{ Beta- catenin nuclear expression } \\
\hline Diffuse & $6(67)$ & $2(10)$ & \multirow[t]{2}{*}{0.003} \\
\hline Negative/ Scattered or Focal & $3(33)$ & $19(90)$ & \\
\hline SATB2 & $4(44)$ & $7(33)$ & 0.687 \\
\hline
\end{tabular}

CAC indicates colitis associated colorectal adenocarcinoma

[34]. This result is contrary to our present study, but may be due to the different methods of LGR5 detection, as the reliability of antibodies against LGR5 remains uncertain $[35,36]$, and most recent studies have used ISH to detect LGR5 expression.

One limitation of our cohort is the limited number of cases and the unavailability of clinical follow up data as well as further molecular analysis. Additional studies using a larger cohort will be needed to determine the relationship between LGR5 expression and clinical prognosis in human CACs.

\section{Conclusion}

Unlike sporadic CRC, LGR5 expression, along with nuclear beta-catenin expression is infrequent in CAC, particularly those with non-conventional morphology. It is more commonly expressed in CAC with conventional morphology and in tumors located in the rectum, indicating that a limited subset of CACs may arise through the conventional $A P C$ pathway. While the precise mechanisms for the low frequency of LGR5 expression in $\mathrm{CAC}$ remains undefined, the wider spectrum of tumor morphology in CAC may be associated with absence of a LGR5-expressing intestinal stem cell phenotype.

\section{Abbreviations}

LGR5: Leucine-rich repeat-containing G-protein-coupled receptor 5;

CRC: Colorectal adenocarcinoma; CAC: Colitis associated colorectal

adenocarcinoma; LGTG: Low grade tubuloglandular

\section{Acknowledgements}

Not Applicable.

\section{Disclosure}

All authors have no financial relationships relevant to this publication.

\section{Authors' contributions}

Each author has participated sufficiently in the work to take public responsibility for appropriate portions of the content: $\mathrm{Ml}$ contributed to the conception and design of the study. MI, $\mathrm{HO}$ and JC analyzed

histopathological features and drafted the manuscript. RR provided valuable advice and suggestions as a histopathologic consultant. TN and TU 
contributed to part of the RNA-ISH study. All authors read and approved the final manuscript.

\section{Funding}

The authors did not receive any funding

\section{Availability of data and materials}

All data generated and analyzed during the current study are available from the corresponding author on reasonable request.

\section{Ethics approval and consent to participate}

Study approval was obtained from the Research Ethics Board at Mount Sinai Hospital. The investigation was conducted in compliance with the Helsinki Declaration.

\section{Consent for publication}

Not applicable.

\section{Competing interests}

The authors declare that they have no competing interests" in this section.

\section{Author details}

'Department of Pathology and Laboratory Medicine, Mount Sinai Hospital, Toronto, Canada. ${ }^{2}$ Department of Laboratory Medicine and Pathobiology, University of Toronto, Toronto, Canada. ${ }^{3}$ Department of Laboratory Medicine, Shinshu University Hospital, 3-1-1 Asahi, Matsumoto, Nagano, Japan. ${ }^{4}$ Department of Clinical Laboratory Sciences, School of Health Sciences, Shinshu University, Matsumoto, Japan.

Received: 24 May 2020 Accepted: 25 January 2021

\section{Published online: 04 February 2021}

\section{References}

1. Eaden JA, Abrams KR, Mayberry JF. The risk of colorectal cancer in ulcerative colitis: a meta-analysis. Gut. 2001;48(4):526-35.

2. Lutgens MW, van Oijen MG, van der Heijden GJ, Vleggaar FP, Siersema PD, Oldenburg B. Declining risk of colorectal cancer in inflammatory bowel disease: an updated meta-analysis of population-based cohort studies. Inflamm Bowel Dis. 2013;19(4):789-99.

3. Olen O, Erichsen R, Sachs MC, Pedersen L, Halfvarson J, Askling J, Ekbom A, Sorensen HT, Ludvigsson JF. Colorectal cancer in ulcerative colitis: a Scandinavian population-based cohort study. Lancet (London, England). 2020;395(10218):123-31.

4. Barker N, van Es JH, Kuipers J, Kujala P, van den Born M, Cozijnsen M, Haegebarth A, Korving J, Begthel H, Peters PJ, et al. Identification of stem cells in small intestine and colon by marker gene Lgr5. Nature. 2007; 449(7165):1003-7.

5. Al-Kharusi MR, Smartt HJ, Greenhough A, Collard TJ, Emery ED, Williams AC, Paraskeva C. LGR5 promotes survival in human colorectal adenoma cells and is upregulated by PGE2: implications for targeting adenoma stem cells with NSAIDs. Carcinogenesis. 2013;34(5):1150-7.

6. Fan XS, Wu HY, Yu HP, Zhou Q, Zhang YF, Huang Q. Expression of Lgr5 in human colorectal carcinogenesis and its potential correlation with betacatenin. Int J Color Dis. 2010;25(5):583-90.

7. Uchida H, Yamazaki K, Fukuma M, Yamada T, Hayashida T, Hasegawa H, Kitajima M, Kitagawa Y, Sakamoto M. Overexpression of leucine-rich repeatcontaining G protein-coupled receptor 5 in colorectal cancer. Cancer Sci. 2010;101(7):1731-7.

8. Baker AM, Graham TA, Elia G, Wright NA, Rodriquez-Justo M. Characterization of LGR5 stem cells in colorectal adenomas and carcinomas. Sci Rep. 2015;5:8654

9. Barker N, Ridgway RA, van Es JH, van de Wetering M, Begthel $H$, van den Born M, Danenberg E, Clarke AR, Sansom OJ, Clevers H. Crypt stem cells as the cells-of-origin of intestinal cancer. Nature. 2009;457(7229):608-11.

10. Kim HS, Lee C, Kim WH, Maeng YH, Jang BG. Expression profile of intestinal stem cell markers in colitis-associated carcinogenesis. Sci Rep. 2017;7(1):6533.

11. Robles Al, Traverso G, Zhang M, Roberts NJ, Khan MA, Joseph C, Lauwers GY, Selaru FM, Popoli M, Pittman ME, et al. Whole-exome sequencing analyses of inflammatory bowel disease-associated colorectal cancers. Gastroenterology. 2016;150(4):931-43.
12. Yaeger R, Shah MA, Miller VA, Kelsen JR, Wang K, Heins ZJ, Ross JS, He Y, Sanford E, Yantiss RK, et al. Genomic alterations observed in colitisassociated cancers are distinct from those found in sporadic colorectal cancers and vary by type of inflammatory bowel disease. Gastroenterology. 2016;151(2):278-287.e276.

13. Iwaya M, Ota H, Tateishi Y, Nakajima T, Riddell R, Conner JR. Colitisassociated colorectal adenocarcinomas are frequently associated with nonintestinal mucin profiles and loss of SATB2 expression. Modern Pathol. 2019; 32:884.

14. Ukpo OC, Flanagan JJ, Ma XJ, Luo Y, Thorstad WL, Lewis JS Jr. High-risk human papillomavirus E6/E7 mRNA detection by a novel in situ hybridization assay strongly correlates with p16 expression and patient outcomes in oropharyngeal squamous cell carcinoma. Am J Surg Pathol. 2011;35(9):1343-50.

15. Jang BG, Kim HS, Chang WY, Bae JM, Kim WH, Kang GH. Expression profile of LGR5 and its prognostic significance in colorectal Cancer progression. Am J Pathol. 2018;188(10):2236-50.

16. Kobayashi M, Honma T, Matsuda Y, Suzuki Y, Narisawa R, Ajioka Y, Asakura $\mathrm{H}$. Nuclear translocation of beta-catenin in colorectal cancer. $\mathrm{Br} J$ Cancer. 2000;82(10):1689-93

17. Becker L, Huang $\mathrm{Q}$, Mashimo $\mathrm{H}$. Immunostaining of Lgr5, an intestinal stem cell marker, in normal and premalignant human gastrointestinal tissue. TheScientificWorldJournal. 2008;8:1168-76.

18. Zheng Z, Yu H, Huang Q, Wu H, Fu Y, Shi J, Wang T, Fan X. Heterogeneous expression of $\mathrm{Lgr} 5$ as a risk factor for focal invasion and distant metastasis of colorectal carcinoma. Oncotarget. 2018;9(53):30025-33.

19. Martin ML, Zeng Z, Adileh M, Jacobo A, Li C, Vakiani E, Hua G, Zhang L, Haimovitz-Friedman A, Fuks Z, et al. Logarithmic expansion of LGR5(+) cells in human colorectal cancer. Cell Signal. 2018;42:97-105.

20. Horst D, Kriegl L, Engel J, Kirchner T, Jung A. CD133 expression is an independent prognostic marker for low survival in colorectal cancer. $\mathrm{Br}$ J Cancer. 2008;99(8):1285-9.

21. Tai MH, Chang CC, Kiupel M, Webster JD, Olson LK, Trosko JE. Oct4 expression in adult human stem cells: evidence in support of the stem cell theory of carcinogenesis. Carcinogenesis. 2005;26(2):495-502.

22. Wang J, Levasseur DN, Orkin SH. Requirement of Nanog dimerization for stem cell self-renewal and pluripotency. Proc Natl Acad Sci U S A. 2008; 105(17):6326-31.

23. Yasuda H, Tanaka K, Okita Y, Araki T, Saigusa S, Toiyama Y, Yokoe T, Yoshiyama S, Kawamoto A, Inoue Y, et al. CD133, OCT4, and NANOG in ulcerative colitis-associated colorectal cancer. Oncol Lett. 2011;2(6):1065-71.

24. Buczacki SJ, Zecchini HI, Nicholson AM, Russell R, Vermeulen L, Kemp R, Winton DJ. Intestinal label-retaining cells are secretory precursors expressing Lgr5. Nature. 2013;495(7439):65-9.

25. Kim TH, Saadatpour A, Guo G, Saxena M, Cavazza A, Desai N, Jadhav U, Jiang L, Rivera MN, Orkin SH, et al. Single-cell transcript profiles reveal multilineage priming in early progenitors derived from Lgr5(+) intestinal stem cells. Cell Rep. 2016;16(8):2053-60

26. van Es JH, Sato T, van de Wetering M, Lyubimova A, Yee Nee AN, Gregorieff A, Sasaki N, Zeinstra L, van den Born M, Korving J, et al. Dll1+ secretory progenitor cells revert to stem cells upon crypt damage. Nat Cell Biol. 2012; 14(10):1099-104.

27. Ishibashi F, Shimizu H, Nakata T, Fujii S, Suzuki K, Kawamoto A, Anzai S, Kuno R, Nagata S, Ito G, et al. Contribution of ATOH1 (+) cells to the homeostasis, repair, and tumorigenesis of the colonic epithelium. Stem Cell Rep. 2018;10(1):27-42.

28. Hartman DJ, Binion DG, Regueiro MD, Miller C, Herbst C, Pai RK. Distinct Histopathologic and molecular alterations in inflammatory bowel diseaseassociated intestinal adenocarcinoma: c-MYC amplification is common and associated with mucinous/signet ring cell differentiation. Inflamm Bowel Dis. 2018;24(8):1780-90.

29. Asfaha S, Hayakawa Y, Muley A, Stokes S, Graham TA, Ericksen RE, Westphalen CB, von Burstin J, Mastracci TL, Worthley DL, et al. Krt19(+ )/Lgr5(-) cells are Radioresistant Cancer-initiating stem cells in the Colon and Intestine. Cell Stem Cell. 2015;16(6):627-38.

30. Yan KS, Chia LA, Li X, Ootani A, Su J, Lee JY, Su N, Luo Y, Heilshorn SC, Amieva $M R$, et al. The intestinal stem cell markers Bmi1 and Lgr5 identify two functionally distinct populations. Proc Natl Acad Sci U S A. 2012;109(2):466-71.

31. Sato K, Uehara T, Iwaya M, Nakajima T, Miyagawa Y, Suga T, Ota H, Tanaka E. Correlation of clinicopathological features and LGR5 expression in colon adenocarcinoma. Ann Diagn Pathol. 2019;40:161-5. 
32. Chen $Q$, Zhang X, Li WM, Ji YQ, Cao HZ, Zheng P. Prognostic value of LGR5 in colorectal cancer: a meta-analysis. PLoS One. 2014;9(9):e107013.

33. Jiang Y, Li W, He X, Zhang H, Jiang F, Chen Z. Lgr5 expression is a valuable prognostic factor for colorectal cancer: evidence from a meta-analysis. BMC Cancer. 2016;16:12.

34. Kazama S, Kishikawa J, Tanaka T, Hata K, Kawai K, Nozawa H, Ishihara S. Immunohistochemical expression of CD133 and LGR5 in ulcerative colitisassociated colorectal cancer and dysplasia. In vivo (Athens, Greece). 2019; 33(4):1279-84.

35. Barker N. Adult intestinal stem cells: critical drivers of epithelial homeostasis and regeneration. Nat Rev Mol Cell Biol. 2014;15(1):19-33.

36. Kemper K, Prasetyanti PR, De Lau W, Rodermond H, Clevers H, Medema JP. Monoclonal antibodies against Lgr5 identify human colorectal cancer stem cells. Stem cells (Dayton, Ohio). 2012;30(11):2378-86.

\section{Publisher's Note}

Springer Nature remains neutral with regard to jurisdictional claims in published maps and institutional affiliations.

Ready to submit your research? Choose BMC and benefit from:

- fast, convenient online submission

- thorough peer review by experienced researchers in your field

- rapid publication on acceptance

- support for research data, including large and complex data types

- gold Open Access which fosters wider collaboration and increased citations

- maximum visibility for your research: over $100 \mathrm{M}$ website views per year

At BMC, research is always in progress.

Learn more biomedcentral.com/submissions 